\title{
China and the Global Financial Crisis
}

\author{
Albert Keidel \\ Senior Associate, Carnegie Endowment for International Peace
}

Despite China's strong current financial and economic position, a focus on China can help highlight how this current global crisis is just another step in the evolution and improvement of the world's governance systems.

China cannot make the mistake of viewing this crisis as a sign of weakness in the political and economic systems that have emerged over centuries in the world's most scientifically and commercially advanced nations. Those systems are still works in progress, and China needs urgently to learn as much as it can from them-including the lessons they are gleaning or hopefully will glean from this current financial and economic crisis.

The United States similarly cannot fruitfully view the resolution of the current crisis as a return to what was there before. The crisis must be seen as an opportunity for major reform and renewal.

For centuries, the world's most advanced systems of political and economic management have progressed in their most rapid spurts during times of crisis such as this. China and the United States, with the rest of the world community, have to roll up their sleeves together to ensure that we gain maximum advantage from the opportunities offered by the world's turmoil today.

In this broader context, this essay focuses most intently on China's current situation, the nature of the global crisis, how it affects China, and what the United States and China together can do with it to gain maximum long-term improvements for themselves and the world at large.

This essay's broader import, however, is its encouragement for all global parties to engage the crisis with a strong sense of promise and opportunity. Let us seize the moment.

\section{China's current economic prospect}

How is China doing? What is its economic situation? The short answer is, China is doing quite well. It is insulated from the financial side of the turmoil, has low inflation, and is growing rapidly. What is more, a review of China's current economic status reveals that China now has

This essay, with updates and extensions through October 26, is based on a luncheon speech Albert Keidel delivered for the U.S.-China Business Council at the Fairmont Hotel in Washington, DC on October 16, 2008. Permission has been granted by the author to reprint this article here.

Albert Keidel is a Senior Associate, Carnegie Endowment for International Peace. He holds a Ph.D. from Harvard and has been a Senior Economist for the World Bank in Beijing and has been acting director of the Office of East Asia Nations at the US Treasury Department. He currently teaches at Georgetown University. 
the freedom to pursue further stimulus of its domestic economy at the same time that its financial system gives it the capability to fund such an expansion. Most significantly, this combined capability is domestic in nature. It is largely independent of the world's current financial woes and can rely on domestic demand and domestic funding. It is also important to note that China's foreign exchange reserves are an insignificant part of this basic domestic funding capability.

This positive view of China's immediate prospects is controversial. There are many uncertain ingredients that could contribute to a more difficult time for China. But all of them imply either implausible combinations of events or an excessively slow and inflexible Chinese policy response. Given benign conditions in China and many recent strong statements by China's leaders, such a weak Chinese policy response now seems most unlikely.

\section{China's trade surplus}

In terms of an implausible combination of events, consider China's trade surplus in 2007, which was 9 percent of GDP. If China suddenly had balanced trade in 2008 and nothing else happened, annual expansion of Chinese GDP output would drop from 12 percent in 2007 to 3 percent. Could this really happen? No, it is too far along in 2008 for this to happen. So far in the first three quarters of 2008, the surplus has only dropped 3 percent, not the 100 percent it would take to balance trade. Yes, the third quarter's surplus alone saw a drop of 9 percent from a year earlier, so one might suppose that things could still badly unravel in the fourth quarter. But for China to suffer balanced trade in 2008, exports would have to fall by 60 percent in the fourth quarter, from positive growth of 17 percent in the third quarter, with import growth staying steady at a positive 25 percent. Nothing remotely like this has a chance of occurring.

This essay is not the place to lay out the many possibilities going forward, but a few numerical what-ifs in a couple of paragraphs can clear up a lot concerning China's near-term reliance on trade.

For the rest of 2008, we could realistically see fourth-quarter export growth go negative, from positive 17 percent in the third quarter to, say, minus 5 percent, but China's exports use so many imported parts and ready-to-assemble kits that import growth would almost certainly also slow. Import growth has already slowed in the third quarter-from 32 percent to 26 percent. Suppose imports also slowed, but not as much as exports, to around 10 percent (though logic suggests that imported parts for use in an expected declining export market would decline even faster). In the case just posed, the quarterly surplus would more than halve from a year earlier. But the annual surplus would only drop 20 percent and GDP growth for all of 2008 would end up at 9 percent, even if growth of domestic demand stayed unchanged. So, GDP growth for the fourth quarter could slow to just under 7 percent, but there is not going to be a catastrophic drop in GDP growth for all of 2008.

What about 2009? If we do the math, China's exports could realistically drop by 20 percent while imports less realistically won't drop nearly as much — say 10 down percent-then the yearly surplus drops 60 percent to 2 percent of GDP. Without any major change in domestic demand, GDP growth would still be 9 percent. With a drop in exports most severe in the first half, GDP growth could average between 6 and 7 percent in the first two quarters before 
recovering in the second half. If export and import growth begin a modest recovery in 2010, with little change in domestic demand, GDP growth could easily pass 10 percent.

How can this be, if China's trade surplus drops so sharply, even to a deficit in 2010? The main answer is, because domestic demand, after cleaning out price inflation effects, has already accelerated in the second and third quarters of this year, to 13 percent, after a less propitious first quarter at less than 9 percent. This recent surge in domestic demand is the real power behind China's good chances for getting through the global economic crisis with high single-digit GDP growth.

\section{China has beaten inflation and now wants to re-stimulate domestic demand.}

China today has just finished a successful 14-month round of inflation-fighting domestic economic tightening. Worrisome inflation erupted in June 2007, largely in the food sector. The roots of this inflation are to be found in the 2003 SARS epidemic and the government's resulting overstimulation of the economy - an inflationary influence that was repressed fairly well in 2005 and 2006, until pork, noodle, milk and egg prices exploded early in the summer of 2007. But that is a longer story than this essay can accommodate.

The critical point is that after more than a year of tighter credit and strenuous investment jawboning, China's consumer price index- when taken month-on-month with appropriate seasonal adjustments - actually declined nearly one percent in August. This wasn't the headline figure of 4.9 percent - because the headline figure is a year-on-year statistic (comparing price levels in August with August a year ago). The year-on-year statistic carries with it twelve months' worth of price increases, including during China's severe snow storms last winter. So, the good news is that for now, China has tamed inflation. Falling oil prices - as of this writing down well below $\$ 70$ a barrel and dropping - are another reason why China's earlier inflation worries can take a policy back seat for now.

In a nutshell, Beijing is poised to stimulate its domestic economy even further. It signaled as much when it lowered loan interest rates a month ago - well before the eruption of the current financial crisis and related coordinated international interest rate reductions.

\section{China's domestic demand}

Beijing has also just finished its third Party plenum meeting following last year's oncein-five-years Party Congress. China likes to use these "third plenum" meetings for taking major decisions because it was at the third plenum in 1978 that China launched its whole post-Mao reform and commercial opening program. One of this recent plenum's decisions is that government will use new domestic stimulus programs to counter expected weakening exports. Its boldest moves in this regard involve strengthening rural household consumption demand, where there is considerable room for upside stimulus. A pledge to double rural incomes and carry out a new phase in rural land reform is the main component of the consumption stimulus program. Real investment growth in the third quarter was well over 15 percent. Third-quarter combined rural and urban household income was up more than 11 percent after correcting for inflation. This combination of investment and consumption growth indicates a good chance for success in reaching the government's domestic stimulus objective—at least in the near term. 
There are also reports that China is readying a new expansion in its domestic housing and office construction programs. China's housing sector has slumped this year under the influence of the anti-inflationary credit tightening program. As China rapidly urbanizes, there is a strong need for rapid growth in affordable housing, and government projects are aware of it. The funding for such projects depends less on interest rates and more on new building permits and relaxation of administrative influences on the scale and composition of bank lending. Such administrative measures have been part of China's mix of fiscal and monetary policy for three decades. Housing demand will also respond to continued rapid growth of household incomes.

\section{China's financial sector is in good shape.}

To carry out this new phase of economic stimulus, China has an especially effective financial system. The strength and versatility of China's financial sector is seldom recognized. But rather than being the troubled sector that some analysts make it out to be, China's financial sector is in fact operating in what is probably an optimal way for the challenges facing China in this early stage of its economic development. Not only is it well designed to withstand domestic contagion from the international crisis; it is also especially suitable for injecting stimulus spending in strategic sectors and locations.

China's financial sector has three parts, each of which contributes to its overall effectiveness.

First, China's market-based financial sector is immature but improving. It is going to need several decades to catch up with Hong Kong's level of sophistication. It is reforming fast, yes, but it has a long way to go. The whole system has been protected from unwise investments by China's tight management of international investment flows. This so-called “closed" capital account supervision is in fact a substitute regulatory system for an unsophisticated domestic financial system. Capital controls have worked well. They allow China's monetary policy to remain independent of international influences while also promoting a high degree of exchange rate stability and predictability.

The second part of China's financial sector is policy-directed lending from its stateowned banks for infrastructure and other public investments. China's low level of development translates into weak tax revenues compared to public investment needs. Government-sponsored bank lending for highways, ports and other lower-return investments is one of the most important reasons for China's long-term economic success. It has helped create the public space in which China's private and other competitive enterprises can do so well.

Finally, the most important source of investment funding in China is not the banks. It is not the stock market or the government. It is corporate retained earnings and private equity contributions. This money goes to competitive, for-profit companies - through decisions by on the-spot managers, directors, family members and business partners. This financing is thus highly market-based and results-oriented-in a word, efficient.

Given how much of China's domestic investment is from competitive profit-seeking sources, couldn't China face its own Keynesian downward spiral of weak consumption causing weak investment, causing weak consumption and so forth? Yes, such a tendency could 
strengthen. But this is where China's record of swift and fully funded intervention, as in 1991, 1998-99, and 2003, indicates there will be little hesitation to step in with both budgetary spending and robust credit expansion. It may take one or two quarters to become fully operational, but the financial and budgetary systems are set up to function well in these circumstances.

Hence, far from representing an economic liability the way other countries' financial sectors do at the moment, China's financial sector is well positioned to finance the next phase in its economic expansion. Recently released results for the third quarter of this year show 9.9percent growth for the year to-date. As already mentioned above, GDP growth for 2008 will likely be 9 percent for the year. With inflation under control for now and additional domestic stimulus on the way, 2009 will see high single-digit growth, and in 2010, growth approaching 10 percent is likely.

This is China's current situation. Inflation is down and government has both the tools and policy position to stimulate domestic demand. Short term trade contraction could slow growth for several quarters, but not longer. China faces the global crisis from a position of strength.

\section{Causes of the global crisis-lots of blame to go around}

What is the nature of the global economic crisis with which China must now contend, and what caused it? Does the nature of the crisis pose hidden risks for China? In all its dimensions, the causes emanate from domestic American and European developments. As I explain below, and despite certain media-centered claims, China did not cause the subprime mortgage crisis. The causes of the global crisis include recent factors that are well known in addition to several factors that span many decades.

\section{Worsening income distribution}

One long-term factor is income distribution in the United States. Inflation-corrected income for a large group of Americans has stagnated for decades, leaving a significant portion of the American work force, in truth, without the income levels needed to afford a house. But in the early part of this decade, this group of families was tempted, seduced or conned, depending on your viewpoint, into mortgages with "small print."

My own five-year-old's Latin American nanny has a daughter who, with her construction worker husband, bought a house with a mortgage which they told me later had "small print" that meant their payments suddenly started going up fast, just when his job situation soured. They lost their home and car and had to move out-of-state to get construction work near a military installation. As we know, this story is all too common.

Recognition that America's income distribution has deteriorated in recent decades, by the way, helps us consider the issue of whether we should bail out homebuyers who "should have known better." In one sense, the same decades of exaggerated free-market thinking that teed up the financial crisis also suppressed income earning standards at the lower end of our economic spectrum and left this large group of families especially vulnerable to the sellers of subprime mortgages. In this context, families facing foreclosure may indeed deserve assistance. What 
changes have to come in our political system if we are to begin correcting this long-term shortcoming in the fundamental underpinnings of American economic health?

\section{Campaign finance, lobbyists and regulatory failure - a kind of corruption?}

Another long-term contributor to the crisis is the American system of funding political campaigns and its companion system of enormous latitude for paid lobbyists to remind politicians of their financial dependence on well-organized donors. The financial sector has traditionally been the single largest funder of elections, both congressional and presidential. Beginning at least as early as the 1990s the requirement placed on politicians in return for election support was legislation and policy implementation to limit the scope of financial regulation and on top of that to starve regulatory institutions of the resources, staff and funding, needed to enforce the regulations already on the books.

In this important sense, then, one underlying cause of the current financial crisis is this systemic flaw in our own democratic political system.

I recently attended an event where one soon-to-retire U.S. senator made a short speech and explained the crisis by saying that financial innovation "increased just too fast for regulatory agencies to keep up!” But the record is clear that this is not the case. Former top-level regulators report that the financial sector worked hard through its lobbyists to weaken the existing regulatory system and prevent it from expanding to keep up with these innovations.

This same U.S. senator was asked about the U.S. Senate rules that allowed retired members access to the Senate gymnasium, where, even as paid lobbyists, they can stay in close contact with their former colleagues still engaged in America's legislative business. The senator’s immediate response was, “Oh! Don’t take that away!”

\section{New financial instruments— not a bad thing if well regulated}

Of course, the proliferation in recent decades of new and more sophisticated financial institutions is an important factor in explaining the current financial crisis. There is nothing wrong with new and sophisticated financial instruments by themselves, as long as they proliferate in ways that don't threaten the whole financial system. New financial instruments can make valuable contributions to the more efficient operation of the overall economy-if they are adequately regulated.

This time, of course, the new instruments were not adequately regulated. That was no accident, as we have seen. It will take this crisis and its aftermath to develop adequate regulatory systems. Or at least, let's hope that is the case. It is less likely that we will see reforms meaningfully reducing the influence of powerful lobbyists, but that is an ambitious hope we can keep in mind. At least as far as subprime mortgages, hedge funds, credit default swaps and the like go, OECD financial regulatory systems will almost certainly have developed adequate regulatory capabilities within ten years’ time.

Twenty or thirty years from now, when China has a more sophisticated financial system than it has now, it will want to know how to regulate its emerging derivatives markets. It will study the solutions we will have crafted by then. For example, the rating agencies that passed 
judgment on the quality of securitized mortgages are paid by the seller or potential seller of a security - their assessments in hindsight were wildly off — in part because no regulatory system disciplined necessary transparency in the industry, but also because they had conflicts of interest. Even the buyers of complex securities, like mutual funds and pension funds-who give the rating agencies a good part of their business - don't want rating agencies to be too aggressive in re-rating instruments they already hold in light of evolving circumstances. How should rating agencies earn their revenue? The system sorely needs reform.

\section{Federal Reserve System’s monetary policy}

With stagnant incomes and dysfunctional regulatory bodies as a backdrop, America was a crisis waiting to get started. Fueling the crisis, beginning in 2001 and 2002, was the Federal Reserve System's overly exuberant use of monetary policy to pull us out of a recession in ways that put a lot of emphasis on construction and housing markets. It went on for too long with too much liquidity. It is easy to under-appreciate the enormous financial clout of the Fed, but it is clearly the most powerful player in this game. Its capabilities dwarf the influence of any one country's reserves or sovereign wealth fund. Compared to the Fed, China and other international creditors are two-bit players.

\section{A bubble is born.}

When mortgage markets combined the Fed's easy availability of finance with poorly regulated mortgage instruments and their securitized loss of lender responsibility, a housing price bubble was born. Late in the game, mortgage guarantors like Fannie and Freddie piled on, but the evidence seems to show they were not responsible for the bubble itself. By 2004-05, the bubble was ready to pop. The popping took a long time, but pop it did.

\section{Balance sheet breakdown}

At this point, the crisis began to show up in the balance sheets of financial firms, but it took a while for the nation to learn just how widespread the interlocking tentacles reached. Now we know.

After that, government mistakes, to my mind, made the balance sheet problems even worse. Most importantly, allowing Lehman Brothers to go bankrupt, rather than taking it over, recapitalizing it and selling it again, not only suddenly made big holes show up on the asset side of everybody's balance sheets, it also shattered the somewhat comforting thought that government would not let the whole system go down in ruin. But it did in fact let the whole system go down in ruin. As a result, interbank lending and commercial credit markets suddenly froze up because of huge uncertainties about whose assets were really worth anything.

And so here we are today, with global governments taking extraordinary steps to loosen up the credit markets, keep banking systems afloat, pump confidence back into stock markets and restore something of what had been there before. I don't think we can go back. We have to go ahead, on a different path, to financial recuperation. 


\section{Did China Cause the Subprime Mortgage Crisis?}

The idea that China is responsible for the U.S. housing bubble and subprime mortgage crisis first attracted attention when the then newly installed governor of the Central Bank of Canada, Mark Carney, said as much in his inaugural speech as governor in early February of this year. The Toronto Globe and Mail gave his thesis considerable coverage. The idea had no traction, however, and seemed to have died.

Then, President Bush earlier this month mentioned mysterious "foreign capital inflows" in his first televised explanation of the financial crisis, without naming China specifically. Subsequently, major American newspaper opinion columns and think-tank analysts have named China as a significant contributor to the onset of the crisis.

Because this thesis is gaining in circulation, it deserves presentation, but the evidence shows it has no good foundation in the actual sequence of developments responsible for the crisis.

The argument that China has a good share of responsibility for the crisis goes something like this: Since China has such a high savings rate and with that such a large trade surplus (so the argument goes), it has recycled its large export earnings back into the U.S. economy, especially into markets for long-term capital, resulting in too much money chasing too few housing assets.

The argument continues by asserting that this large cash influx kept interest rates low and that it pumped up overly strong demand for housing and for mortgages, many of which had long term automatic interest rate increase features. A slightly more sophisticated version blames the Federal Reserve System for not adequately handling the rush of Chinese money into the American economy. Either way, China's trade surpluses, and by extension its exchange rate and other commercial practices are made out to be important causes of the crisis.

The only problem with this narrative is the inconvenient timing of China's trade surpluses, its reserves growth, and the housing bubble. The overly frothy housing market in the United States first began gathering bubbles in 2000 and 2001. It was in high gear in 2003 and 2004. But China's global trade surpluses were small until the end of 2004, when China began an earlier phase of anti-inflation economic tightening. Other countries-Germany, Japan, and even the combination of Singapore and Malaysia — had much larger global trade surpluses than China during the period when the American housing market became so hot.

Even after China's imports weakened in 2005 and its global trade surplus grew dramatically, the issue is not that China was selling to the United States, but rather that the United States, on net, was buying unprecedented levels of goods and services from the whole world, not just China. This purchasing power for foreign goods and services reflected the general availability of short-term credit to American consumers and businesses.

What is more, the dollar-denominated parts China's foreign exchange reserves, even today, pale in comparison to the cash and credit generating capabilities of the U.S. Federal Reserve System for adjusting the American money supply and influencing shifts in American interest rates. 
The idea that China caused the financial crisis is somehow comfortable and reassuring to some, because it implies that the crisis is not so much a failure of America's policies and system as many maintain. It is clear from the timing and scale of the housing bubble, however, that this claim is still not persuasive, and we need to dismiss it if we want to understand what has really happened to the developed world's financial systems and, ultimately, to global economic health.

In short, China did not cause the crisis, but the nature of the crisis today requires a close look at how it might affect China.

\section{The evolving crisis today-money's collapse and the aftermath}

In a nutshell, what has happened is the collapse of what is in effect our economy's, and the global economy's, “super” money supply. Strictly speaking, we think of our money supplywhat we use to buy and sell things_-as composed of cash and bank deposits. But in actuality it is much more than that. It is all the channels of communication, the practices, the agreements and contracts that allow different pieces of paper, phone calls, and electronic communications to stand in for circulating money-like credit markets, financial insurance arrangements and even equities in the stock markets, because transactions like mergers and acquisitions frequently involve transfers of stock. This super money supply also includes the habits and practices that allow rapid-fire deals, based on trust that they will work the way they always have. In the run-up to the crisis, the myriad liquidity mechanisms for carrying out economic and financial transactions had reached an impressive scale, a "super” liquidity.

\section{We can't simply resurrect the old system.}

When this whole super liquidity system is functioning smoothly, it enables a wide variety and huge volume of everyday transactions - transactions that make the economic world go 'round. But when it collapses, as it just has, we can't just quickly rebuild it the way it was. We have to inject a lot more of the old-fashioned kinds of money and relationships-cash, bank deposits, government guarantees, and government takeovers- to try and replace what was lost and, hopefully, gradually induce the foundations of the old system to reemerge in a more stable form.

\section{Take over, fix and resell}

Looking ahead, one part of the potential long-term damage caused by the crisis is in the behavior of future financial CEOs and their boards of directors. If government recapitalization of the banking system for example, leaves the interests of current owners intact, there will be little reason for future owners and their managers to worry about taking extravagant risks once again. The lesson they will have learned from this crisis is that the government will save them-save their own personal finances.

Today’s policy makers need to avoid this kind of moral hazard. Government needs to take equity stakes that at a minimum dilute the outstanding equity shares of the financial firms involved. Ideally, if a firm is faced with bankruptcy, current owners should lose everythingwhile depositors' and other creditors' obligations are honored. There is ample precedent for this in the world of developing countries and emerging markets, where governments have taken over 
banks, recapitalized them and then sold them to new owners. This in principle is the approach the British government is taking.

But America's current strategy is different. The Treasury's announcement of its investments in the U.S. banking system noted that diluting the value of existing equity shares "made bank CEOs uncomfortable." Consequently, the so-called "equity stakes" the government is buying are really not that at all-they are preferred shares without voting rights that pay a contracted rate of return. They are not really equities; they are a kind of sophisticated debt instrument. The government does hold the option of converting these preferred shares into real ownership, but if it pours enough money into the troubled firms, that might never happen. Current owners would not lose much over time, if anything.

What is really happening here? It is no surprise that equity dilution would make current bank CEOs "uncomfortable." That is why we hear the campaign to characterize such takeovers as "socialist." But such takeovers are anything but socialist. They are just the opposite. This is the way a good capitalist government can preserve healthy capitalism-healthy capitalism where owners need to be aware of the risks, risks to their own personal fortunes, of making serious mistakes. That is the essence of capitalism.

\section{Exchange rate risk rears its ugly head}

In addition to domestic crises in major - and minor-world economies, we are beginning to see an extension of the overall situation that reminds us of the Asian Financial Crisis of 199798. Countries at that time with newly-and almost certainly prematurely-liberalized international financial flows found that when demand for U.S. dollars strengthened dramatically and the price of dollars rose dramatically as a result, these countries and their enterprises of all kinds could not make good on their international borrowings. They had borrowed in dollars, lent domestically in their domestic currencies, and now weren't getting enough return on their domestic investments to pay back the initial foreign debt, which was now much more expensive because of exchange-rate changes.

We have already witnessed Iceland's urgent need to fix its exchange rate from collapsing by freezing market transactions in foreign currencies while it rationed what foreign exchange it had left for strategic purchases only. It is still looking for international bailouts.

A more worrisome example is South Korea, whose currency weakened another 9 percent in the mid-October weeks of financial turmoil, after having already lost as much as 20 percent of its value earlier in the year. Korea has a large war chest of reserves, and maybe that will be sufficient to insulate it from the kind of meltdown it suffered in the Asian Financial Crisis. Hopefully it will. Singapore in the Asian financial crisis lost foreign reserves equivalent to 23 percent of its money supply. Fortunately, it had reserves to match much more than that. South Korea has reserves worth more than 30 percent of its money supply. Hopefully that will be sufficient.

\section{Recent U.S. intervention in currency markets}

Indeed, the U.S. Federal Reserve System over recent weeks has made as much as $\$ 600$

billion dollars available to foreign central banks to help keep them from having to go to 
international currency markets to buy dollars-a buying pattern that would have driven the value of the dollar up for many currencies. In other words, to keep many world currencies from precipitous devaluation, the American central bank has been helping prevent the U.S. dollar from appreciating. This is interesting, because it is an indirect kind of intervention in currency markets-intended to keep the dollar weak-quite similar to the Chinese government's intervention in its own currency markets intended to keep its currency price from rising. In both cases, U.S. and Chinese intervention, the purpose has been to preserve stability in currency markets.

If the enormous demand for U.S. dollars currently emerging results in the precipitous weakening of different global currencies such that countries and companies can no longer honor their dollar-denominated obligations, this will only add to the holes in developed country balance sheets. It is difficult at this point to know whether this will happen and, if so, how serious the problem could become. The risk is there.

\section{The real non-financial economy—the big enchilada}

Of course, one reason stock markets were so volatile in mid-October was the bad news on the overall U.S. economy-not just its financial institutions. A downward spiral in the real economy is the all but certain next stage in this crisis, and with credit markets still not cleared up and consumer sales shrinking, its impact could be serious indeed.

This would be a classic Keynesian downward spiral—of the sort that John Maynard Keynes explained so well with regard to the Great Depression. It goes like this: consumers slow spending, which signals to firms that they need to slow up their plans for investment in new plant and equipment. This slowing of investment means that employment and wages in construction, machinery, and related sectors will suffer, worsening consumer demand. Firms then invest less; income and consumption weaken further, and so forth.

Compared to the years of the Great Depression, today we have more of a cushion to soften such a downward spiral because of the larger scale of government spending in the economy-including its military components. We also understand these kinds of phenomena much better than we did back then. Still, the crisis this time is global, with the exception of China and to a lesser extent India. The Keynesian downward spiral could surprise us with its virulence.

This is where the crisis is today. It is still unfolding, especially on the real economy front. It is not a pretty picture.

\section{Where the crisis goes depends on the policy response}

What shape the crisis takes depends on the policy-making effectiveness in the world's leading economies. On the financial front, global efforts to pump old-fashioned liquidity into the economy are essential, but as mentioned above, they need to avoid the moral hazard inherent in the current U.S. formulation. Even if some semblance of normalcy returns to banking, credit, and equity markets, the many months this will take means that the real economic downturn will then be more serious than usual. 


\section{Only deficit spending on an adequate scale can revive the real economy.}

Keynes described how in such situations, lowering interest rates will not do much to stimulate a recovery. That is almost certainly true today-especially with credit markets still wound up tightly. Instead, it takes government spending directly into the economy to create jobs and restore consumer incomes and purchasing power.

The needed extra spending in a recession must always be funded with a degree of government borrowing, and in a normal recession, this happens automatically. Tax revenues inevitably fall as the economy weakens while central government spending stays up and sustains its cushion of demand. If the recession is abnormally severe, as this one promises to be, additional deficit spending is essential.

Who lends all this money to the Treasury? In the last resort, the Federal Reserve System does. It is as simple as that. We do not have to rely on China. China is not America's banker. Isn't this inflationary? Won't this be a huge burden on future American taxpayers-our grandchildren? No, because such debt, held by the Fed and other investors, can be retired after decades of strong economic growth, as was the case in the 1990s, when economic boom, not any genius of policy making, generated budget surpluses that threatened to pay off all U.S. government debt.

And no, such deficit spending doesn't have to be inflationary if demand is shrinking and prices as a result are soft if not falling. What is more, it matters a great deal where the spending is injected into the economy. If it goes to buy products and services from regions, sectors and pools of labor with high unemployment and excess capacity, there is no inflationary pressure.

One of the most effective ways to use federal funding to support the economy would be in the form of grant assistance to state governments on a large scale. States, counties and municipalities are faced with shrinking revenues and difficulties borrowing in the many normal ways states sell their bonds for both temporary and long-term needs. At the same time they have infrastructure projects ready to go and staffs threatened with layoffs who are performing useful government services - in education, for example — spending on which could quickly use federal money to help rebuild consumer and investment demand.

\section{U.S. political resistance to deficit spending could be a problem.}

One of the more worrisome aspects of the looming recession is the American political system's professed aversion to deficit spending at any time-even at times like this. It becomes too easy in a political charged environment to accuse a political opponent of fiscal irresponsibility, when in fact the irresponsible policy would be not to spend the funds needed to avoid a much deeper recession.

The American national government is not a family sitting around the kitchen table, trying to figure out how to make ends meet. The federal government is responsible for the financial and economic health of the nation. This means above all else ensuring that there is sufficient liquidity in the economy and enough sustained demand to bring employment to optimal levels. This is the requirement of laws passed after World War II instructing U.S. leadership how to conduct economic policy. If it takes deficit spending to accomplish this statutory goal, so be it. 
Should the American economy arrive at some future point, following economic recovery, when too much liquidity in the economy threatens inflation, the Fed can remove liquidity by selling a portion of the treasury bonds it holds, and the Treasury can use its by-then-recovered tax revenues to retire a portion of the debt as well. Again, this has happed recently, in the latter 1990s, when booming dot-com output brought budgetary surpluses to the federal government. In one sense, the Treasury got close to paying off the national indebtedness it originally incurred during World War II — the deficit spending that finally got us out of a Great Depression that had lingered for well more than ten years.

If political opposition to adequate levels of spending results in a downward spiral of consumption and investment spending, it will be even more expensive later, and even more difficult politically, to try and spend our way out of the recession.

\section{China will avoid both dimensions of the current crisis.}

Both aspects of this evolving financial and economic crisis pose little direct threat to China. Neither the financial chaos on credit markets and bank balance sheets, nor the threatening collapse of effective economic demand will force China to join most other nations in the world in their economic downturns. Indeed, even though its economy is still relatively small in the global commercial scheme of things, China can help provide a minor degree of cushion for the world, as its own continued domestic-driven economic expansion generates a modicum of demand for output from recession-stricken economies.

\section{China is insulated from the financial dimensions of global crisis}

As far as the financial crisis is concerned, China's mainland has remained safely isolated from the global turmoil. Its so-called "closed" capital account is not really closed to financial flows, but it has managed and restricted international financial transactions effectively enough to prevent large-scale investments in troubled assets. This practice in China contrasts with practices in other countries, rich and poor, with "open" capital accounts.

What is more, China's banking system at this early stage in its economic development is still essentially government-owned or government-controlled. China has shown in the past ten years that it is able and willing to intervene to maintain the health of its banking system. At this point, the status of China's banks makes intervention of the kind now common around the world highly unlikely.

China's stock market has of course seen a dramatic fall in prices over the past year, but this has nothing to do with the world's financial woes. China's stock market is in its infancy and has by law very little foreign participation. It is also buffeted by shifts in government regulations and uncertainties about how many government-held shares might be suddenly dumped on the market. It is rife with speculative behavior on the part of citizens and enterprises, and its record of instability over the past fifteen years has shown virtually no relationship with the plight of the real economy. It crashes and booms play out in a world of their own, and most smart investors in China know better than to put their most strategic assets into play. 


\section{China doesn't need to rely on exports for growth.}

Similarly, as we have seen, China is fairly well insulated from the downturn in global demand, with the possible exception of several quarters in the winter and spring of 2008-09. Unlike most of America's major trading partners, China's GDP fluctuations over recent decades are not linked to U.S. booms and busts. Instead, they follow the lead of domestic economic policy. When China's trade surplus surged in 2005-07, on top of strong domestic demand growth, it led to overheating.

A common misconception is that China's GDP growth is export-led. Growing evidence shows it is not and never has been. My own recent work, China's Economic Fluctuations, supported by the Ford Foundation, shows that over thirty years, not one of Mainland China's ups and downs was related to trade or coupled with the ups and downs in American GDP growth. This is different from Japan, South Korea, Hong Kong, Taiwan, and Singapore - not to mention, say, Germany and the Netherlands.

An even more recent study by economists at the Hong Kong Monetary Authority1 makes the same point from a totally different analytical perspective, showing that the major stimulus to China's long-term growth was the productivity gains associated with imports, not the demand associated with exports.

So, yes, China's export surplus growth will slow, and yes the surplus may even shrink or disappear. But the driver for China's economy has always been domestic demand, not exports. China's domestic demand last year, in 2007, expanded at an 11.5-percent rate, accounting for more than 9 percentage points of China's 12-percent growth. We have already seen how domestic demand in the second and third quarters of this year grew at 13 percent, without any special policy stimulus.

\section{Lower world prices will benefit China.}

Will domestic demand from China help maintain global energy and raw material prices? No, it will not. By itself, China's commercial activity is not sufficient to do so. Nor will China want to see world commodity prices stay high. Indeed, China will likely do a head fake for a few quarters, as it continues to back out of contracts for oil and other basic imports that were priced much higher than in today's markets. I mean "head fake" in the sense that China's behavior and public statements might make it seem that it has fewer needs than in fact will be the case. China is not going to want to look like such a strong source of demand until after prices for energy and metals, for example, have come down further. China's several quarters of slow growth coming up, as its trade surplus adjusts downward, will help give credibility to the price bargaining process.

After that, China will enjoy several years of low input prices just as it ramps up its domestic demand in a new phase of GDP expansion. Sure, China will be a strong source of ${ }^{1}$ demand, but only after oil and other prices have stabilized at lower levels. This import

\footnotetext{
${ }^{1}$ He, Dong and Wenlang Zhang, "How Dependent is the Chinese Economy on Exports and in What Sense has its Growth been Export-led?”, Hong Kong Monetary Authority working paper 14/2008
} 
affordability will include machinery, other technologies and talent of all kinds, in addition to basic materials.

The timing of China's coming domestic-based expansion, just as the world's major economies contract, is thus one of the major reasons why China will do so well during the coming global slump.

\section{China will continue to attract foreign investment.}

China's domestic-based growth going forward is likely to continue to attract foreign investment, especially FDI (foreign direct investment). Since China's accession to the WTO, production for China's domestic market has always been an important part of the foreign investors' incentives, but with the global slowdown and China's continued if not accelerating growth in domestic demand, access to Chinese domestic markets from Chinese production platforms will become even more significant.

Data for the first three quarters of 2008 in fact show this already to be the case. Actual foreign investment flows were up 40 percent from a year earlier, a dramatic acceleration. Of course, such investment brings with it technology and managerial talent, as it always has. This pattern is just one additional dimension of the general advantage China will be able to gain because of its own economic vitality at a time of general decline in the rest of the world.

\section{The global financial crisis and U.S.-China relations}

This financial crisis and China's relative position of strength raise concerns for both short-term and long-term relations with the United States. In the short-term, trade protectionism and quasi-protectionist issues like China's exchange rate, could gain political traction despite their flawed statistical and logical justifications.

In the longer-term, a continuing Chinese economic expansion coupled with slower than expected U.S. growth will only bring forward the day when China's entire economic scale will be larger than America's - with all the commercial, diplomatic and military reassessments this trend implies. The need for America to begin now a major adjustment in its doctrines for global governance is made more urgent by the current crisis.

\section{Protectionism is a concern.}

Despite the lack of a Chinese role in causing or worsening the current crisis, it could become easy for politicians and other politically active media elements to accuse the U.S. administration and Congress of doing too little to prevent alleged Chinese commercial misbehavior. Politicians will need to defend their own seats, and challengers will be looking for issues that might resonate with the electorate under conditions of nationwide stress in employment and income.

Fortunately, the current U.S. political campaign is coming too soon for the impact of recession to encourage any significant role for protectionist sentiments. But the election of 2010 could easily be a different story. Both the United States and China need to take steps to avoid the mutual harm that such a development would entail. 
The one exception to the current hiatus in unwarranted criticism of China's commercial practices is with regard to China's exchange rate policies. This essay is not the place for a detailed review of this issue, but it is useful to note that the efforts of various well-paid American and European lobbyist groups to continue to push this issue have resulted in what has become increasingly heavy-handed pressure on the International Monetary Fund to alter its surveillance standards to fit the needs of U.S. and European politicians.

The most tangible result so far is the delay this fall in the IMF's publication of its most recent surveillance report on China. At the behest of Europe and the United States and through pressure from IMF senior leadership on permanent staff, the most recent review, known as an "Article IV" review, based on private accounts of its content, features poorly justified accusations that China's currency is insufficiently flexible and in effect undervalued to a degree that represents a Chinese "manipulation of its currency to gain an unfair trade advantage." China, as is its right under IMF information privacy provisions, has refused to allow public release of the surveillance report because of its disagreement with the worth of the underlying analysis.

\section{America's posture toward China's economic, diplomatic and military rise}

The U.S. handling of short-term commercial developments has relevance for the evolution of longer-term relations in ways optimal for serving U.S. national interests.

In other publications I have demonstrated how-even with conservative assumptions about continued U.S. growth and significantly decelerating Chinese growth-China would nevertheless overtake the U.S. economy in total size shortly after 2030. These calculations use commercial exchange rate predictions for their comparisons, making them even more sobering.

The outbreak of the current global recession and China's immunity from its impact on growth and modernization around the world alters those assumptions in ways that imply China's economy could easily be larger than America's even earlier, well before 2030. The United States must begin considering now how it wants to participate in global governance challenges twenty five years hence, when it will no longer be the largest economy in the world. These same trends imply China’s economy will be double its U.S counterpart before 2050.

These developments require a reassessment of U.S. global strategies and military doctrine. Without going into detail here, we need only note China's just-completed successful space walk and its stated objective of putting a man on the moon. United States doctrine, as I understand it, currently intends to deny any other country peer-competitor status in space-based military platforms. Is this realistic? An alternative basis for serving America's own best interests going forward is to begin exploring now a framework for establishing peer-partner cooperation in space with China, as part of a shift from the current U.S. doctrine for managing global affairs.

\section{Shades of the 1930s?}

Fortunately, circumstances today are very different than those facing the country in 1929, or when Franklin Roosevelt won the presidency in 1932. Governments in the United States, Europe and Japan have a larger permanent presence in their economies, affording them some limited degree of cushioned stability. More importantly perhaps, we have a much better understanding of how a macro economy works in times of crisis like this, thanks in large part to 
the writings of Keynes and his followers, including the current U.S. Federal Reserve Chairman, Mr. Bernanke.

What hasn't changed since the 1930s is America's popular aversion to an adequate role for government in managing these crises and in laying the groundwork for a healthy economy, an economy that would have greater resistance to the repetition of such crises in the future.

Roosevelt and his congresses required themselves to be so constrained in terms of the nature and scale of government spending in a crisis that they never succeeded in pulling America out of the Great Depression. Despite all their programs, they failed. Only the sizeable deficitspending outlays during World War II finally succeeded in pulling America out of economic stagnation - with annual deficit spending on the order of 20 percent of GDP. But throughout the 1930s, the U.S. national debt remained roughly constant, so small was the scale of deficit spending. When Roosevelt himself tried to improve the federal budget balance in 1936-37, he plunged the nation into a severe worsening of the depression-at that late a stage in the 'thirties economic hardships.

The Congress and both presidential candidates today find themselves caught in the same situation where Roosevelt found himself-competing for the upper hand with rhetoric about fiscal responsibility, arguing, sadly, about where to find the money in other programs to pay for a stimulus package. That is the wrong challenge. The right challenge is how to spend more money wisely on other programs in addition to funding the financial stimulus package. It is an open question today whether the American political process can permit the federal government to undertake actions necessary to limit the severity of this coming recession.

As a Great Depression footnote, it is interesting to remember that Japan in the 1930s was able to change its economic policies in the direction of domestic-led economic stimulus based on government spending - and not just for military expansion. This economic success took an ugly turn in a world environment at the time, when existing world powers had already sewn up their colonial and quasi-colonial empires and Japan felt, however wrongly from today's perspective, that its economic status entitled it to some similar level of participation in what was at the time standard international operating procedure.

Standard procedure today is thankfully very different, and China has shown it is a responsible participant in helping manage explosive situations, from North Korea to Pakistan and beyond. But standard international procedure today also includes a preponderance of U.S. and European influence in the management of international organizations like the IMF. If these parties continue to use this traditional influence to pressure China in ways that too narrowly serve their own political and strategic interests, it could undermine the potential for the more broad-based collaborative approach to managing global issues that must surely evolve if future commercial, diplomatic and military developments are to serve America’s long-term interests.

\section{U.S. and Chinese policy options in light of the current global economic crisis}

For the most part, China and the United States have different policy responsibilities in the current crisis circumstances-with one exception. They both need to focus on avoiding developments from the crisis that could amplify commercial and diplomatic disputes-especially 
in the longer term. They cannot allow the crisis to undermine the collaborative relationship necessary for China's economic rise to proceed peacefully in coming decades.

The world's advanced economic and political systems have a chance to make major improvements in their own operations, thanks to this crisis. This crisis must be allowed to play its potentially positive role in helping America and the world craft a system of global governance that works well for all peoples. Such improvements can only serve to strengthen U.S.-China mutual respect and improved relations. Both sides should work hard to maximize such success.

\section{In these times, put aside frivolous short-term commercial posturing.}

In a superficial and short-term perspective, the United States should back off its specialinterest- affiliated focus on China's exchange rate and acknowledge that it is just too early to know what the role of one price - the exchange rate-will turn out to play in China's trade relations, once the huge shifts of its WTO accession and global turmoil have settled down. This is not the time for America to be throwing its weight around - through IMF pressures or in other ways-for a goal that is so contentious and so weakly supported by analysis.

At the same time, China also can set aside its traditional posturing to limit its import growth, for example, when China insists that its slower import growth only reflects western, especially U.S., restrictions on sale of advanced dual-use technologies. That may be a factor in understanding China's trade balance, but the many Chinese non-tariff barriers still in operation are for the time being potentially much more significant. Business as usual, protecting certain sectors and regions, inhibits China from making adequate contributions to global effective demand at this time of looming worldwide contraction.

\section{America's major economic priority must be preventing a serious depression.}

The major U.S. task at hand is global economic recovery. Financial system rescue must be just part of that effort. America has to lead a two-step worldwide recovery effort.

This effort at self-correction and, in a sense, American renewal, is also essential for healthy U.S.-China relations. China risks misunderstanding the significance of this crisis as some sign of failure of market-based, democratic, and yes, capitalist, institutions. Instead, on a very positive path, this crisis can be understood as just one more painful step forward for a whole system of national and - hopefully global — governance based on competition regulated by public institutions committed to fairness and justice in opportunity for all parties. China needs to appreciate this point, and so do we.

This American effort at economic renewal should, first, restore adequate liquidity through well-targeted infusions of cash, credit, and guarantees into all necessary dimensions of the world's financial institutions and their transactions. This process seems already well under way. Critical requirements are speed and adequate scale. The mechanisms employed cannot be permanent, but they can prop up the financial side the world's economic systems while more sophisticated and competitive dimensions put themselves back together again - this time in a healthier, better regulated, form. 
At the same time America needs to do this in ways that avoid the moral hazard of saving the personal finances of those business owners responsible for serious mistakes. The basic process has to have some component of taking businesses away from those who mismanaged them, recapitalizing or otherwise restoring overall health to those businesses, and then reselling them to new owners. This is hardly socialism. It is instead the best way to strengthen the healthy underpinnings of a competitive capitalist global financial system.

Second, America must join leading economies of the world in the need to implement fiscal spending on a scale adequate to avoid a severe recession if not depression. This is probably America's greatest political challenge- to agree to carry out such a large program. It may be that the incentive to carry out such a program will have to come from a much more ambitious set of efforts in Iraq and Afghanistan-not just military moves but a collection of measures that the new president can persuade the American people is necessary in the war on terror. It could require substantial levels of spending in the U.S., for labor and matériel, on a scale that could be both large enough to avoid depression and politically palatable enough for public and congressional acceptance. It might also make a difference in the war on terror.

As part of this process, the United States has a particularly important job in persuading two of its major allies, Germany and Japan, to reflate their economies in ways that lead to longterm trade deficits rather than their traditionally large surpluses, so that they, like the United States, can perform the needed role of generating effective demand for the exports of so many impoverished nations in the world.

Beyond these two short-term measures, longer-term essential steps include regulatory reform to bring new financial instruments to heel as well as reforms severely limiting the activities and access of professional lobbyists. The commonly heard argument is that such lobbyists are only exercising their rights to free speech. But professional lobbying isn't really free speech, it is paid speech, and the law ought to make a distinction between the two. These would be substantial political reforms, and they would greatly strengthen American democracy if done well. Such is one promise in our current set of crisis-born opportunities.

Other longer-term priorities are well known but worth mentioning, health care reform, educational reform, trade and technology adjustment assistance, and energy reforms all will have direct bearing on the future health of the overall American economy. To the degree that these reforms are successful, America can be a better example for China, and other developing countries, of workable options for building a modern society.

Success in taking these policy steps would in effect dramatically alter what Americans see as an appropriate role for government in maintaining the efficient functioning of a just and opportunity-based capitalist market economy. The whole world's understanding of good governance would advance. If there is a silver lining to the global financial and economic crisis, this would be it. 


\section{China's priority is "steady as she goes" with some adjustments.}

China needs, of course, to continue to follow through with its stimulus for domestic demand expansion at the same time that it also implements the wide range of social and environmental reforms it has recently outlined. But this is not enough, given the global crisis.

It would be helpful if China continued to emphasize its intention of conducting a balanced and responsible program for managing its foreign exchange reserves. Many observers of the crisis, especially in the United States, exaggerate the significance of these reserves. But even if fears of disruptive Chinese exchange-rate strategies are unfounded, China could nevertheless still contribute to global stability and public confidence by frequently reiterating its intention to follow a benign reserve management philosophy.

More tangible benefits could come from steps China could take to weaken non-tariff trade barriers and significantly accelerate growth of imports relative to exports. Such a policy move could have two advantages in the context of the crisis. First, stronger Chinese import demand would both help crisis-stricken economies expand output and employment and restore confidence that U.S. and European exports can help solve macroeconomic demand problems. Second, if China's import growth accelerated to a point where imports exceeded exports, then China would have a global trade deficit, and it would be impossible for protectionist elements or other special interests to argue that China's trade practices were unfair.

Finally, China could tone down and improve its criticisms of American and European financial mismanagement. China could go a long way toward encouraging a more constructive interpretation of the crisis. Rather than only condemning U.S. and European economic leaders for causing this crisis, China could, and should, point out that crises like this one have always provided the impetus for improvements in the conduct of financial sector business and its regulation by government.

For well over a hundred years, financial market regulation has improved most when crisis has shown up its shortcomings. This current crisis will clearly be just another chapter in the gradual, and uneven, process of making an ever increasingly sophisticated financial system function more fairly and more efficiently. This is the most helpful-and most accurateinterpretation of the crisis' long-term significance. As an outsider to the crisis, China could play the role of objective commentator and strengthen confidence worldwide in the eventual if not speedy recovery everywhere. 